11. UAE and Saudis form new partnership separate from GCC. 5 December, 2017. URL: https://www.aljazeera.com/news/2017/12/uae-saudi-arabia-form-political-partnership171205075923016.html

12. Doha's attitude keeps it isolated from neighbors. The Arab Weekly. 03 June, 2018. URL: https://thearabweekly.com/dohas-attitude-keeps-it-isolated-neighbours

13. Katar gotovij nadati Ukrayini skraplenij gaz - glava derzhavi. 20 bereznya 2018 [Katar is ready to deliver Ukraine liquefied gas - Head of State]. URL: http://www.president.gov.ua/news/katar-gotovij-nadati-ukrayini-skraplenij-gaz-glava-derzhavi-46522

14. President Ukrayini proviv zustrich z vice-premierom, ministrom zakordonnyh sprav Kuveyta, 2018, 18 bereznya [The President of Ukraine conducted meeting with the vice-premier-minister, minister of foreign affairs of Kuwait]. URL: http://www.president.gov.ua/news/prezident-ukrayini-proviv-zustrich-z-vice-premyer-ministrom-46466

15. Subh, M. Transfomatsiyni procesi v krainah Rady spivrobitnitstva arabskyh derzhav Zatoky v procesah globalizacii (2001-2010 rr.) [Transformations processes in Arab Gulf States (2001-2010)]. Abstract of Ph. D. thesis. Kyiv, 2015.

16. Shved, V. O. «Arabska vesna» v konteksti suchasnyh transformactiynyh procesiv na Blizkomy i Serednyomy Shodi [ «Arab spring» in the Context of Contemporary Transformations Process in the Near and Middle East]. Problemi vsesvitnyoi istorii: naukovyi zhurnal, 2016, 1, 109-122.

17. Ce potuzniy poshtovh yakiy znachno aktivizuye spivpratcu Ukrayini z krainami Zatoki, 20 bereznya 2018 [This is a strong impuls which significantly actives the cooperation of Ukraine with Gulf States, March 20, 2018]. URL: http://www.president.gov.ua/news/ce-potuzhnij-poshtovh-yakij-znachno-aktivizuye-spivpracyu-uk-46526.

УДК $340.15: 342.7$

\title{
ДОТРИМАННЯ ПРАВ ЛЮДИНИ В ІРАНІ: ЕВОЛЮЦІЯ ПРОБЛЕМИ ВІД МАХМУДА АХМАДІНЕЖАДА ДО ХАСАНА РУХАНІ
}

\section{Пилипенко Вікторія}

Основним завданням автора є спроба показати особливість формування державної політики Ісламської Республіки Іран за президентства Махмуда Ахмадінежада й Хасана Рухані щзодо впровадження та дотримання Деклараџї прав людини і громадянина в усіх сферах суспільного та політичного життя країни.

В основі методологічної бази дослідження покладено загальнонаукові приниипи аналізу та синтезу, метод критичного аналізу джерел та історико-генетичний метод, щьо дали можливість прослідкувати динаміку розвитку ситуації в Ірані навколо дотримання прав людини. У пропонованій статті дослідником було використано системний підхід, завдяки якому вдалося виявити складові елементи побудови іранської державної політики щуодо опозиційних сил, правозахисників та незалежних журналістів. 
Іран залишається державою, де ситуація з дотриманням прав людини знаходиться у неконтрольованому міжнародною спільнотою стані. Найбільше загострення протистояння між правозахисниками та владою спостерігалося під час президентства М. Ахмадінежада, коли почали говорити про тотальну несвободу не лише на політичному, але й на побутовому рівні. Позитивні тенденції з гарантування прав людини намітилися після приходу до влади Х. Рухані. Проведені ним реформи законодавчої системи, прийнята Хартія громадянських прав, попри наявні проблеми, дають можливість говорити про включення Тегерана до правового поля й поступового виходу з міжнародної ізоляиії.

Результати та висновки аналізованої проблеми у перспективі можуть бути використані для порівняння рівня дотримання прав людини в Ірані з іншими державами близькосхідного регіону.

Ключові слова: Іран, Ахмадінежад, Рухані, Декларація прав людини і громадянина, Генеральна Асамблея ООН, хартія, правозахисники, політичні в 'язні.

Прийняття Загальної декларації прав людини у грудні 1948 р. заклало підгрунтя до становлення процедури міжнародного захисту прав людини, де основоположну роль відіграє ООН та створені на його основі правозахисні Міжамериканська й Африканська системи. Подібного регіонального механізму захисту прав людини у державах Перської затоки створено не було. Цей факт започаткував дискусію у наукових колах щодо доцільності актуалізації проблеми з дотримання прав людини у державах Близького Сходу. Так, ще у 1982 р. професор Бутрос Б. Галі зазначав, що домінуючими в арабських державах є проблеми економічного розвитку, оновлення та укріплення суверенітету і безпеки, а тому питання демократії не належать до першочергових у системі державного будівництва $[1,575]$. Тоді як К. Меніович зауважував, що основною перепоною до участі мусульманських держав у міжнародних угодах $з$ прав людини є суто ісламський підхід, що базується на принципах Шаріату та Корані як джерелу права $[9,128]$. Водночас домінування негативних тенденцій у питанні розвитку громадянських прав і свобод у країнах Перської затоки, хоч і надає актуальності дослідженню ситуації з дотриманням прав людини в Ірані в останні десятиліття, але демонструє низьку зацікавленість цим питанням українських іранознавців. Серед українських дослідників, які піднімали питання про дослідження рівня громадянських свобод в Ірані й близькосхідному регіоні загалом, можна назвати К. Меніовича [9] та Я. Коваленко. Більш ширше розглядають питання 3 дотриманням прав людини в Ісламській Республіці Іран (далі - IPI) російські дослідники, зокрема Н. Ганеа [2], Н. Жаданов [3] та С. Челала [21]. Отже, виходячи з актуальності та недостатнього розкриття проблеми у вітчизняній історіографії, мета статті - показати особливість формування державної політики IPI за президентства М. Ахмадінежада й X. Рухані щодо впровадження та дотримання Декларації прав людини і громадянина. Для реалізації поставленої мети в якості джерельної бази дослідження були використані резолюції і постанови Генеральної Асамблеї ООН (далі - ГА ООН) та офіційні заяви іранських високопосадовців.

3 моменту утворення Ісламська Республіка Іран позиціонує себе як претендент на статус регіонального лідера з особливим, не орієнтованим ні на Схід, ні на Захід, шляхом політично-економічного розвитку. Однак, посідаючи 27 місце у світі за по- 
казниками ВВП й маючи одну із найбільш потужних економік в ісламському світі, Іран залишається державою із незадовільним рівнем гарантування політичних і громадянських свобод [17]. Так, за рейтингом становища політичних і громадянських свобод у державах світу, що проводяться міжнародною неурядовою організацією Freedom House, IPI займає 185 позицію з 210 та належить до держав із повною відсутністю свободи [18].

Доволі гостро проблема порушення прав людини в Ісламській Республіці постала за часів президента Махмуда Ахмадінежада і проявилася у вигляді масових арештів опозиційних активістів у ході та після президентських виборів 12 червня 2009 р. За ініціативи президента були організовані обшуки і катування правозахисників, студентів, журналістів, арешти демонстрантів [12]. Зокрема, усі можливі факти порушення прав людини за наказом іранського президента, а саме: тортури, страти, організовані на найвищому рівні з порушенням міжнародних договорів, побиття камінням, репресії і дискримінація проти жінок, зазначалися у Резолюції ГА ООН від 18 грудня 2009 р. Резолюція, прийнята для попередження розгортання масових урядових чисток, висловлювала глибоке занепокоєння відмовою Ірану співпрацювати 3 експертами, наділеними спеціальними мандатами ООН щодо моніторингу і попередження порушення прав людини [13]. Постійний представник IPI в ООН Мохаммад Хазаї різко розкритикував цей документ, назвавши його «політично вмотивованим, що провокує конфронтацію і поляризацію» [7]. Однак заяви М. Хазаї не лише не були взяті до уваги, але й розцінювалися як прямий крок до міжнародної ізоляції Ірану, що набувала реальних обрисів після введення у липні 2010 р. США чергових антиіранських санкцій. Підписаний американським президентом Обамою «Закон про всеохоплюючі санкції по відношенню до Ірану, притягненні до відповідальності і дивестування» містив перелік посадових осіб, причетних до придушення антиурядових виступів 2009 р., що потягли за собою порушення прав іранських громадян-протестувальників або членів їхніх сімей [19]. Подібні заходи ООН за сприяння Вашингтону сприяли тому, що у 2011 р. М. Ахмадінежад все ж погодився з рішенням Ради ООН з прав людини про призначення Спеціального доповідача у сфері прав людини в Ірані [12].

Надані факти нового витка порушення прав людини в Ірані лише доповнювали загальну несвободу, що проявлялася у вигляді широкого застосування смертної кари, у тому числі і до неповнолітніх, відрізання кінцівок, фізичної ліквідації політичних опонентів і борців за реалізацію прав жінок.

Найбільш гучними стали справи Шаді Садр, Рахелех Азгарізаде та Насім Хосраві, які виступали за розширення прав жінок. Приміром, адвокат Шаді Садр, яка виступала захисником учасників демонстрації 2006 р. за ліквідацію законодавчого закріплення дискримінації жінок, сама була позбавлена волі за звинуваченнями в антидержавній діяльності. Двом іншим жінкам при арешті у лютому 2008 р. під час збору підписів за розширення прав жінок інкримінували «пропаганду проти державного устрою», що передбачає позбавлення волі до шести місяців [4, 13-16]. 
Значно впливає на сприйняття IPI як держави без свободи затвердження на рівні Кримінального кодексу застосування смертної кари по відношенню до неповнолітніх. Згідно з даними агентства Франс-Пресс, у 2007 р. було повішено 298 осіб (включаючи дітей), а у 2008 - 117 осіб. Станом на 2017 p. Amnesty International у ході розслідування підтвердила факти виголошення смертних вироків 4 неповнолітнім особам $[16,54]$. При цьому, у звіті наголошувалося, що подібні судові рішення щодо осіб, молодших за 18 років, порушують умови міжнародних договорів - Пакту про цивільні і політичні права, Конвенції прав дитини [21].

Окрім поширеної практики застосування смертної кари і побиття камінням (стаття 119 кримінального кодексу регламентує навіть розмір каміння, щоб смерть засудженого не наставала одразу після одного-двох ударів) Іран є лідером у близькосхідному регіоні за кількістю політичних в'язнів та ув'язнених іноземних громадян $[3,374]$. Щодо останніх, то доволі гучним виявився судовий процес над двома американськими туристами - Джейн Брауер та Джош Фатал - заарештованими влітку 2009 р. при перетині іранського кордону з боку Іраку та звинуваченими у шпигунстві 3 подальшим відбуванням 8 років тюремного ув'язнення. При цьому ініціатива М. Ахмадінежада відпустити арештантів як символ доброї волі напередодні сесії ГА ООН зустріла рішучий спротив з боку представників судової системи і викликала внутрішньополітичну кризу [10].

Непоодинокими також $є$ факти порушення прав представників релігійних меншин, особливо бахаїстів: несанкціоновані рішенням суду затримання, тривалі терміни ув'язнення, тортури і жорстоке поводження, примусове закриття підприємств і заборона займати державні посади. Увагу громадськості було зосереджено на долі бахаїстської сім'ї Рахім'янів, в якій обох із подружжя позбавили волі за викладання в Бахаїстському інституті, а неповнолітніх дітей передали під опіку літній бабусі $[2,139]$. Марні спроби спеціального уповноваженого ООН з прав людини домогтися звільнення викладачів змусили його у березні 2013 р. констатувати, що «становище бахаїстів в Ірані є одним із найбільш очевидних випадків переслідування з боку держави» [8].

Дещо позитивна тенденція у справі дотримання прав людини в Ірані намітилася 3 приходом до влади у серпні 2013 р. Хасана Роухані, який позиціонує себе як поміркований політик, готовий до компромісу з країнами Заходу у вирішенні ряду спірних питань. Під час передвиборчої агітації він, зокрема, виступив із проектом «Хартії громадянських прав», що передбачає рівність усіх громадян без будь-якої дискримінації за ознаками раси, віросповідання і статі. У ній також передбачалося надання більшої свободи політичним партіям і національним меншинам, а також право на справедливий судовий розгляд, свободу зібрань і правовий захист кожного [11].

Обговорення проекту Хартії розпочалося з січня 2014 р., коли в мережу Інтернет було запущено декілька технічних планів з покращення ситуації у дотриманні прав людини. Остаточний варіант документа був опублікований у грудні 2016 р. та викликав значну дискусію серед експертів, які знайшли в Хартії цілий ряд недоліків: відсутність поняття «громадянство», а отже, й розуміння гарантування прав особі- 
громадянину, відсутність механізму реалізації положень документа, особливо у тій частині, що регламентує права жінок, тощо [20].

Увесь процес підготовки до підписання Хартії перебував під пильним контролем Генасамблеї ООН та міжнародних правозахисних організацій. Так, у прийнятій 19 грудня 2014 р. Резолюції більшу увагу було приділено співвідношенню між де-юре і де-факто ліквідації дискримінації національних меншин, жінок, розробленню механізму притягнення до відповідальності за порушення прав людини, у тому числі й судові органи та служби безпеки [14]. Поруч із Резолюцією ГА ООН щодо ситуації 3 дотриманням прав людини в Ірані світовій громадськості було представлено Доповідь Сари Лі Уітсон, директора організації Human Rights Watch, де зазначалося, що Іран залишається однією із найбільших у світі в'язниць для журналістів і блогерів. Також зауважувалося, що влада продовжує систематично блокувати веб-сайти, знижує швидкість Інтернету і глушить іноземні супутникові трансляції [6].

Негативна тенденція щодо обмеження вільного доступу до веб-сайтів і сторінок у соцмережах зберігалася станом на 2016 р., про що свідчить судова заборона на відкриття доступу до Facebook, Twitter та YouTube. Досить показовою є відмова уряду підтримати судову заборону на блокування популярного мессенджера Telegram [16, 48]. Значні позитивні кроки у напрямі узгодження іранського законодавства 3 міжнародною нормативно-правовою базою у сфері захисту прав людини були відзначені на черговому засіданні ГА ООН. Прийнята 19 грудня 2016 р. Резолюція зазначила позитивні зміни до окремих розділів Кримінально-процесуального кодексу, готовність іранської сторони прийняти афганських біженців із гарантуванням доступу до основних послуг, а також відкритість Високої ради з прав людини до діалогу зі Спеціальним доповідачем з питань про становище у сфері прав людини в Ірані [14].

Однак, чергові президентські вибори у 2017 р. та пов'язані з ними арешти представників опозиційних сил, тримання під вартою правозахисників, придушення акцій протесту проти корупції і політичних репресій викликали занепокоєння міжнародних організацій, що знайшло вираження у Резолюції ГА ООН. У документі містилися невдоволення фактами обмежень прав на свободу думок, совісті, релігії й переконань, а також великої кількості оголошених смертних вироків щодо злочинів неповнолітніх. При цьому реакція Тегерана була вкрай негативною, а сама Резолюція ООН названа документом, що підтримує спонсорів тероризму і є такою, що підриває «вищий статус прав людини» [5]. Проте, подальшого напруження у відносинах між країнами-членами ООН та Іраном, попри прогнози деяких політологів, не відбулося. Свідченням досягнення компромісу двома сторонами стала Резолюція ГА ООН від 19 грудня 2017 р., де було відзначено позитивні кроки у реформуванні законодавства Ісламської Республіки у напрямку розширення гарантування прав людини та громадянина [15].

Таким чином, Іран залишається державою, де ситуація 3 дотриманням прав людини знаходиться у вкрай тяжкому неконтрольованому стані. Найбільше загострення протистояння між правозахисниками та владою спостерігалося під час президент- 
ства М. Ахмадінежада, коли почали говорити про тотальну несвободу не лише на політичному, але й на побутовому рівні. Позитивні тенденції з покращення ситуації навколо гарантування прав людини намітилися після приходу до влади Х. Рухані. Проведені ним реформи законодавчої системи, прийнята Хартія громадянських прав, попри наявні проблеми, дають можливість говорити про включення Тегерана до правового поля і його поступового виходу з міжнародної ізоляції.

Подальшою перспективою дослідження мають стати спроби компаративного аналізу політики держав Близького і Середнього Сходу з питань дотримання прав людини та відповідності цієї політики нормам міжнародного гуманітарного права.

\section{Summary}

The author's key task is to make an effort in presenting the specifics in the formation of the state policy of the Islamic Republic during the rule of the presidents Mahmoud Ahmadinejad and Hassan Rouhani over the implementation and adhering of the Declaration of Human Rights in each area of the social and political life of the country.

The methodological basis of this research consists of the general scientific principles of the analysis and synthesis, the method of the critical analysis of sources and the historical and genetic approach, which gave the opportunity to observe the unfolding situation in Iran towards the respect for human rights.

In the given article the research worker used the system-wide approach which inspired to bring to light the component elements of the nation building of Iran's state policy concerning the opposition forces, human rights activists and independent journalists.

Iran belongs to those states, where the situation relating the respect for human rights is still uncontrolled. In particular, the radicalization of the opposition between the human rights activists and the authorities became visible during the rule of the president Mahmoud Ahmadinejad, when appeared the talks about the total unfreedom not only in the political but in daily life as well. The positive trends concerning the guarantees of human rights were shown after Hassan Rouhani's coming to power. The reforms of a legislative system undertaken by him, including the adopted Charter on human rights despite the obvious problems allow us to speak about the inclusion of Teheran in the legal framework as well as the gradual end to international isolation.

In the long view, the results and conclusions concerning the analyzed problem can be used for the comparison of the respect for human rights in Iran and the other countries of the Middle East region.

Key words: Iran, Ahmadinejad, Rukhani, Declaration of Human Rights and Citizen, UN General Assembly, charter, human rights defenders, political prisoners.

\section{Аннотация}

Основной задачей автора является попытка показать особенности формирования государственной политики Исламской Республики Иран во время пребывания при власти президентов Махмуда Ахмадинежада и Хасана Рухани в отношении внедрения и выполнения норм Декларации по правам человека и гражданина.

Методологическую базу исследования составляют общенаучные приниипы анализа и синтеза, метод критического анализа источников и историко-генетический метод, которые предоставили возможность отследить динамику развития ситуации в Иране вокруг соблюдения прав человека. В предлагаемой статье исследователем было использовано системный подход, благодаря которому удалось определить составляющие части иранской государственной политики в отношении оппозищионных сил, правозащитников и независимых журналистов. 
Иран остается государством, где ситуачия с соблюдением прав человека находиться на неподконтрольном мировому сообществу уровне. Наиболее остро противостояние между правозащитниками и властью было отмечено во время президента М. Ахмадинежада, когда мировые СМИ начали сообщать о тотальной не свободе не только на политическом, но и на бытовом уровне. Положительные тендениии по предоставлению гарантий соблюдения прав человека наметились после прихода к власти Х. Рухани. Организованные им реформы законодательной системы, принятая Хартия гражданских прав, вопреки имеюшимся проблемам, дают возможность предположить о начале включения Тегерана в правовое поле и постепенном его выходе из международной изоляции.

Результаты и выводы проанализированной проблемы в перспективе могут быть использованы для проведения сравнительного анализа уровня соблюдения прав человека в Иране с другими странами ближневосточного региона.

Ключевые слова: Иран, Ахмадинежад, Рухани, Декларация прав человека и гражданина, Генеральная Ассамблея ООН, хартия, политические заключенные.

\section{ДЖЕРЕЛА ТА ЛІТЕРАТУРА}

1. Boutros Ghali. The League of Arab States. Karel Vasak. Dimensions of human rights. Westport: Greenwood Press. 1982. Vol. 1. P. 575-580.

2. Ганеа Н. «Бахаист за рулем»: типология религиозной дискриминации. Equal Rights Review. 2016. № 16. С. 139-160.

3. Жаданов Н. В. Права человека в исламе. Москва: Наука, 2003. 789 с.

4. Защита прав человека в меняющемся мире / Amnesty International. Лондон, 2008. 62 с.

5. Иран назвал резолюцию по правам человека ГА ООН неприемлемой. URL: https://tass.ru/mezhdunarodnaya-panorama/4732780 (дата звернення: 10.12.2018).

6. Иран: нарушение прав человека продолжаются при новой администрации. URL: https://www.hrw.org/ru/news/2014/01/21/252399 (дата звернення: 10.12.2018).

7. Комитет ООН осудил нарушение прав человека в Иране. URL: https://korrespondent.net/world/1019996-komitet-oon-osudil-narusheniya-prav-cheloveka-v-irane (дата звернення: 10.12.2018).

8. Международное сообщество бахаистов. «Специальный докладчик ООН по вопросу о свободе религии или убеждений обсуждает новый доклад о насилии в отношении бахаистов в Иране». URL: http://News.Bahai.Org/Story/945 (дата звернення: 10.12.2018).

9. Меніович К. О. Права людини в арабських країнах Перської затоки: Арабська хартія прав людини. Актуальні проблеми міжнародних відносин. 2009. Вип. 83. C. $128-130$.

10. Нарушение прав человека в Иране. URL: http://www.iimes.ru/?p=13296 (дата звернення: 10.12.2018).

11. Новый президент Ирана должен выполнить обещания в сфере прав человека. URL: https://amnesty.org.ru/node/2520/ (дата звернення: 10.12.2018).

12. ООН будет отслеживать положение в области прав человека в Иране. URL: https://amnesty.org.ru/node/1809/ (дата звернення: 10.12.2018). 
13. Положение в области прав человека в Исламской Республике Иран: Резолюция Генеральной Ассамблеей ООН от 18 декабря 2009 г. № 64/176. URL: https://undocs.org/ru/A/RES/64/176 (дата звернення: 10.12.2018).

14. Положение в области прав человека в Исламской Республике Иран: Резолюция Генеральной Ассамблеи ООН от 18 декабря 2014 г. № 69/190 URL: https://undocs.org/ru/A/RES/69/190 (дата звернення: 10.12.2018).

15. Положение в области прав человека в Исламской Республике Иран: Резолюция Генеральной Ассамблеии ООН от 19 декабря 2017 г. № 72/189. URL: https://undocs.org/ru/A/RES/72/189 (дата звернення: 10.12.2018).

16. Права человека в мире: доклад Amnesty International о состоянии прав человека в мире. Лондон, 2018. $316 \mathrm{c.}$

17. Рейтинг стран мира по уровню Валового Внутреннего Продукта: информация об исследовании и его результаты. URL: https://gtmarket.ru/ratings/rating-countriesgdp/rating-countries-gdp-info (дата звернення: 10.12.2018).

18. Рейтинг стран мира по уровню политических и гражданских свобод. URL: https://gtmarket.ru/ratings/freedom-the-world/info (дата звернення: 10.12.2018).

19. Справка: Закон о всеобъемлющих санкциях в отношении Ирана, привлечении к ответственности и дивестировании (CISADA). URL: https://www.treasury.gov/ resource-center/sanctions/Programs/Documents/CISADA_russian.pdf (дата звернення: 25.12.2018).

20. Хартия новых прав президента Рухани. URL: https://iranprimer.usip.org/blog/2014/ feb/10/president-rouhani\%E2\%80\%99s-new-rights-charter (дата звернення: 10.12.2018).

21. Челала С. Нарушение прав человека в Иране достигли беспрецедентных масштабов. URL: https://www.epochtimes.ru/content/view/14851/9/ (дата звернення: 10.12.2018).

\section{References}

1. Boutros, Ghali (1982). The League of Arab States. Karel Vasak. Dimensions of human rights [The League of Arab States. Karel Vasak. Dimensions of human rights]. Westport: Greenwood Press, vol. 1, 575-580.

2. Ganea, N. (2016). «Bahaist za rulem»: tipologiya religioznoj diskriminacii [ «Baha'is driving»: a typology of religious discrimination]. Equal Rights Review, № 16, 139-160.

3. Zhadanov, N. V. (2003). Prava cheloveka v islame [Human rights in Islam]. Moskva: Nauka.

4. Zashita prav cheloveka $\mathrm{v}$ menyayushemsya mire [Protecting human rights in a changing world] (2008) / Amnesty International.London.

5. Iran nazval rezolyuciyu po pravam cheloveka GA OON nepriemlemoj [Iran called the UN GA resolution on human rights unacceptable]. URL: https://tass.ru/mezhdunarodnaya-panorama/4732780 (data zvernennya: 10.12.2018).

6. Iran: narushenie prav cheloveka prodolzhayutsya pri novoj administracii [Iran: human rights abuses continue under new administration]. URL: https://www.hrw.org/ru/ news/2014/01/21/252399 (data zvernennya: 10.12.2018). 
7. Komitet OON osudil narushenie prav cheloveka v Irane [UN Committee Condemns Violation of Human Rights in Iran]. URL: https://korrespondent.net/world/1019996komitet-oon-osudil-narusheniya-prav-cheloveka-v-irane (data zvernennya: 10.12.2018).

8. Mezhdunarodnoe soobshestvo bahaistov. «Specialnyj dokladchik OON po voprosu o svobode religii ili ubezhdenij obsuzhdaet novyj doklad o nasilii v otnoshenii bahaistov v Irane» [International Baha'i community. "UN Special Rapporteur on freedom of religion or belief discusses a new report on violence against Baha'is in Iran»]. URL: http://News.Bahai.Org/Story/945 (data zvernennya: 10.12.2018).

9. Meniovich, K. O. (2009). Prava lyudini v arabskih krayinah Perskoyi zatoki: Arabska hartiya prav lyudini. [Human rights in the Arabic countries of the Persian Gulf: Arab Charter on Human Rights]. Aktualni problemi mizhnarodnih vidnosin, Vip. 83, 128-130.

10. Narushenie prav cheloveka $\mathrm{v}$ Irane [Violation of human rights in Iran]. URL: http://www.iimes.ru/?p=13296 (data zvernennya: 10.12.2018).

11. Novyj prezident Irana dolzhen vypolnit obeshaniya v sfere prav cheloveka [New Iranian President must fulfill promises in the field of human rights]. URL: https://amnesty.org.ru/node/2520/ (data zvernennya: 10.12.2018).

12. OON budet otslezhivat polozhenie $\mathrm{v}$ oblasti prav cheloveka $\mathrm{v}$ Irane [UN to monitor human rights situation in Iran]. URL: https://amnesty.org.ru/node/1809/ (data zvernennya: 10.12.2018).

13. Polozhenie v oblasti prav cheloveka v Islamskoj Respublike Iran: Rezolyuciya Generalnoj Assambleej OON ot 18 dekabrya 2009 g. № 64/176 [Situation of human rights in the Islamic Republic of Iran: Resolution of the UN General Assembly of December 18, 2009. № 64/176]. URL: https://undocs.org/ru/A/RES/64/176 (data zvernennya: 10.12.20 18).

14. Polozhenie v oblasti prav cheloveka v Islamskoj Respublike Iran: Rezolyuciya Generalnoj Assamblei OON ot 18 dekabrya 2014 g. № 69/190 [Situation of human rights in the Islamic Republic of Iran: Resolution of the UN General Assembly of December 18, 2014. № 69/190]. URL: https://undocs.org/ru/A/RES/69/190 (data zvernennya: 10.12.2018).

15. Polozhenie v oblasti prav cheloveka v Islamskoj Respublike Iran: Rezolyuciya Generalnoj Assambleii OON ot 19 dekabrya 2017 g. № 72/189 [Situation of human rights in the Islamic Republic of Iran: Resolution of the UN General Assembly of December 19, 2017. № 72/189]. URL: https://undocs.org/ru/A/RES/72/189 (data zvernennya: 10.12.2018).

16. Prava cheloveka v mire: doklad Amnesty International o sostoyanii prav cheloveka v mire (2018) [Human Rights in the World: Amnesty International Report on the State of Human Rights in the World]. London.

17. Rejting stran mira po urovnyu Valovogo Vnutrennego Produkta: informaciya ob issledovanii i ego rezultaty [Rating of countries of the world by the level of Gross Domestic Product: information about the study and its results]. URL: https:/gtmarket.ru/ratings/ rating-countries-gdp/rating-countries-gdp-info (data zvernennya: 10.12.2018). 
18. Rejting stran mira po urovnyu politicheskih i grazhdanskih svobod [Rating of countries of the world in terms of political and civil liberties]. URL: https://gtmarket.ru/ratings/ freedom-the-world/info (data zvernennya: 10.12.2018).

19. Spravka: Zakon o vseobemlyushih sankciyah v otnoshenii Irana, privlechenii k otvetstvennosti i divestirovanii (CISADA) [Reference: Law on comprehensive sanctions against Iran, prosecution and divestment (CISADA).]. URL: https://www.treasury.gov/ resource-center/sanctions/Programs/Documents/CISADA_russian.pdf (data obrasheniya: 25.12.2018).

20. Hartiya novyh prav prezidenta Ruhani [Charter for new rights of President Rouhani]. URL: https://iranprimer.usip.org/blog/2014/feb/10/president-rouhani\%E2\%80\%99snew-rights-charter (data zvernennya: 10.12.2018).

21. Chelala, S. Narushenie prav cheloveka v Irane dostigli besprecedentnyh masshtabov [Violations of human rights in Iran have reached unprecedented proportions]. URL: https://www.epochtimes.ru/content/view/14851/9/ (data zvernennya: 10.12.2018). 